\title{
SiM
}

\section{Estimating Effects of Targeted Conservation on Nonfederal Rangelands}

\author{
By Mark Weltz and Ken Spaeth
}

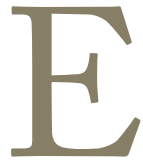

stimating the effects of conservation practices on rangelands is extremely challenging, compared with cropland, because rangelands consist of a mosaic of plant species with highly diverse landscapes of mixed land ownership and management objectives. The checkerboard pattern of land ownership on rangelands in the West, a legacy of 19 th century government homestead and railway construction policies, makes conducting assessments and estimating effects of conservation at landscape or watershed scale a challenging endeavor. This is complicated by the interaction of climate, topography, plants, soil parent material, and land management that interact to yield a mosaic of plant communities over time. Rangeland communities are further influenced by episodic disturbances, such as insect outbreaks, fire, drought, and flood. ${ }^{1}$ The most-developed quantitative indicators of conservation effects currently on rangelands are 1) modeled soil erosion, and 2) the number and types of invasive plant species. These indicators can be used to infer impacts on water availability and quality, wildlife habitat quality or suitability for target wildlife species, forage availability for domestic livestock and/or wildlife, and vulnerability to wildfire, which will directly influence sustainability of the plant community.

A partnership comprising the Natural Resources Conservation Service (NRCS), Agricultural Research Service (ARS), Bureau of Land Management (BLM), and US Geological Survey has worked since the early 1990s to develop a monitoring and assessment system to track the status and health of rangelands. Through this effort, this partnership has developed new on-site data protocols, called the National Resources Inventory (NRI), for assessing the status of rangelands. ${ }^{2,3}$ These protocols, which were initiated by the NRCS in 2003 on nonfederal lands and by the BLM in 2011 on the federal lands it administers, will provide unified monitoring data in the near future for the western United States. Between 2003 and 2006, NRCS sampled more than 10,000 NRI, onsite field segments on native rangelands. The rangeland NRI on-site study follows a national, statistical-sampling strategy, with geographic information system (GIS)-referencing of locations, which makes reporting information simple and powerful for targeting areas that can benefit from conservation.

The ARS and NRCS have recently developed a new process-based model for assessing soil-erosion rates on rangelands, which can provide estimates of soil erosion risks at national, regional, and local scales. The Rangeland Hydrology and Erosion Model (RHEM) was developed from more than 25 geographically distributed, rangeland-erosion experiments across the western United States, representing native grassland, shrubland, and woodland sites. ${ }^{4}$ The RHEM was designed to operate using data available from the NRI and many rangeland-monitoring efforts. Model inputs are surface soil texture, slope length, slope steepness, slope shape, dominant plant life form, percentage of canopy cover, and percentage of ground cover by component (rock, litter, basal area, and microbiotic crusts). Climate (precipitation intensity, duration, and frequency) is estimated for the site with the Cligen ${ }^{i}$ stochastic weather generator included in the model. The Cligen model is run to provide 300 years of daily precipitation records, and RHEM uses that information to estimate the average annual soil loss during a 300-year time span. The model also estimates the 2-, 10-, 25-, 50-, and 100-year return runoff events to provide an assessment of the vulnerability of the site to accelerated soil loss from raindrop splash and sheet-flow soil-erosion processes.

The NRI data were used to parameterize RHEM to estimate hillslope-scale soil loss for the western United States. Soil erosion reporting regions were defined by using a combination of Common Resource Areas (CRAs), Major Land Resource Areas (MLRAs), and Land Resource Regions to form a unique geographic region. Interpretation of quantitative estimates of soil erosion is based on statistically weighted aggregations of NRI sample points collected into polygons

\footnotetext{
'For more on Cligen, see http://www.ars.usda.gov/Research/docs. htm?docid=18094.
} 


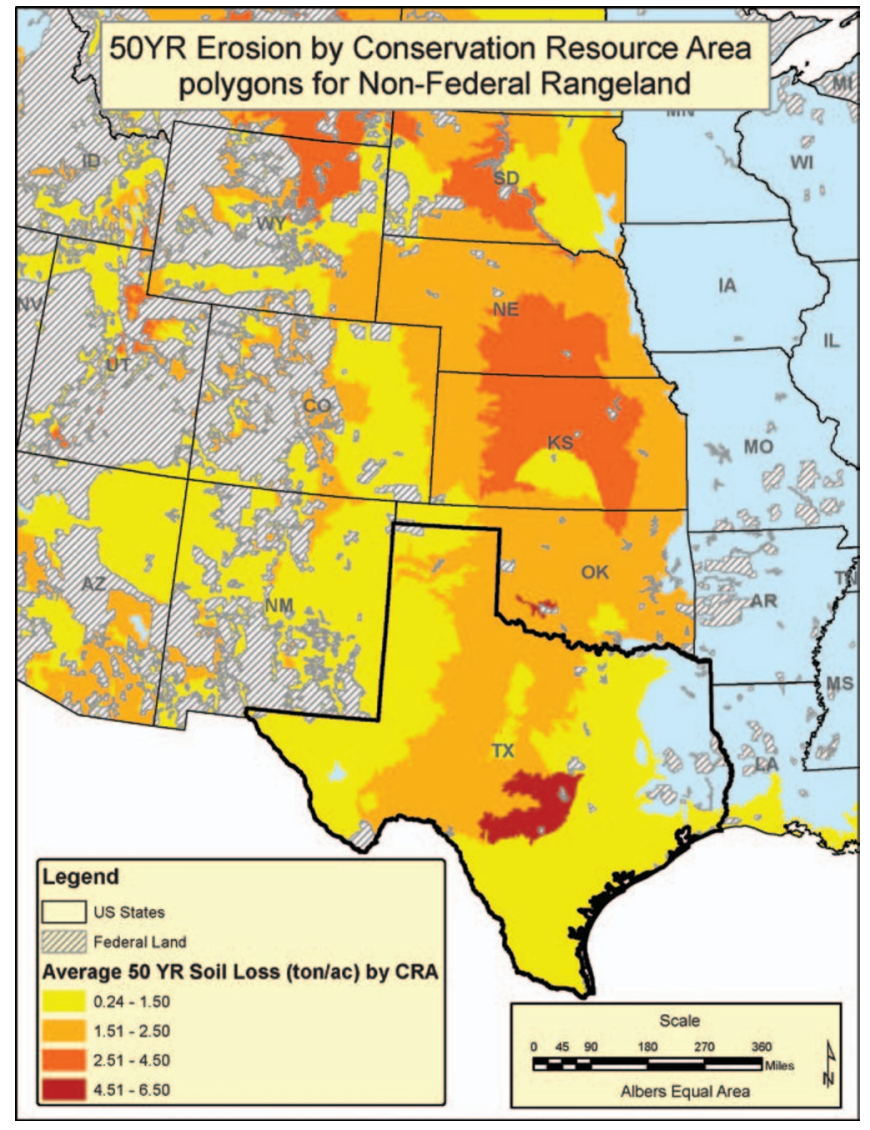

Figure 1. Geographic representation of estimated Rangeland Hydrology and Erosion Model soil loss (tons per acre) from a 50-year return period runoff event for Texas, USA. Data from NRCS NRI rangeland 2003-2006 field assessment.

using the CRAs on measurements with a minimum of 49 NRI sample points per polygon.

The focus of our article is to illustrate how a national assessment, such as the NRI, can be used to target conservation placement to increase the effectiveness of limited funding available for restoration of degraded plant communities and to estimate ecosystem services that would be derived from these conservation efforts.

\section{Effect of Ashe Juniper on Hydrologic Function and Soil Loss: An Example From Texas}

For many arid and semiarid, western rangeland soils, the sustainable soil loss is estimated to be $<1$ ton per acre per year because of their shallow depth, low organic matter content, and the slow rate of soil formation in erratic and dry climates. Soil loss rates of 1-2 tons per acre per year on these types of rangelands put the site at risk of being unsustainable, and soil loss rates of $>2$ tons per acre per year, if not checked, are unsustainable. Approximately $12 \%$, or 48.2 million acres, of nonfederal rangelands are vulnerable to accelerated soil loss from a 50-year return period runoff event. ${ }^{5}$ By using the NRI data displayed in a GIS, it is easy to determine that the Ed-

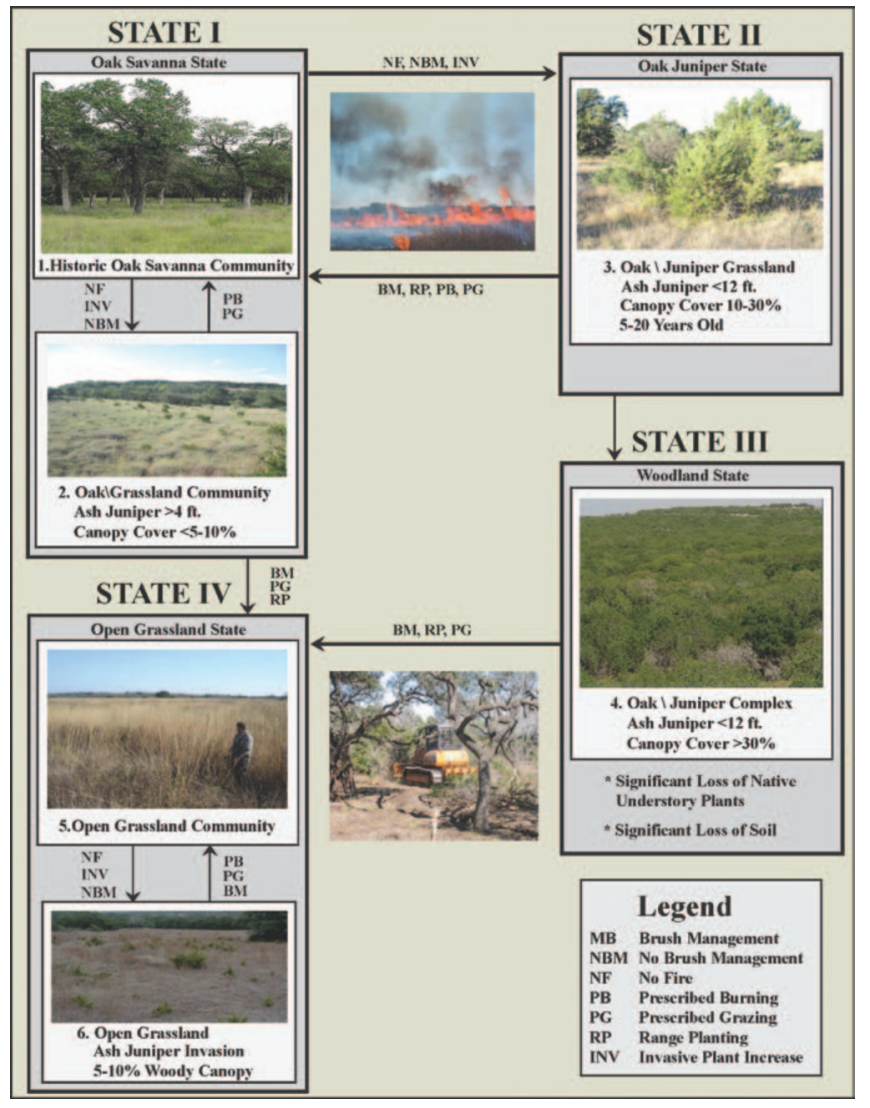

Figure 2. Example of developed Ecological Site Description for Deep Redlands (PE 44+) Ecological Site in the Edwards Plateau near Johnson City, Texas, USA, illustrating State I (reference plant community), possible alternative States II, III, and IV; recovery pathways; and types of conservation practices that are needed to restore a degraded site to the reference plant community (photos by NRCS).

wards Plateau (MLRA 81) has one of the highest potential soil erosion rates from a 50-year return period runoff event (4.5 tons per acre per 50-year event) in Texas, and a high percentage of the cover is Ashe juniper (Juniperus ashei J. Buchholz), an invasive woody plant (Fig. 1).

The eastern portion of the Edwards Plateau is 98\% rangeland, composed of 20 currently identified rangeland ecological sites across 8,060 square miles in central Texas. Limestone ridges and canyons (karst geology) with nearly level to gently sloping valley floors dominate the landscape. Average elevation is 900 feet, and the average annual precipitation in the area is $24-30$ inches. Most of the rainfall occurs in spring and fall. The reference vegetation community is grassland and open savanna plains, with tree or woody species found along rocky slopes and stream bottoms. Tall grasses originally dominated the area, and stocking rates for cattle for the reference plant communities varied from 3 acres per animal-unit month to 10 acres per animal-unit month, depending on the ecological site. The reference plant community for the Deep Redlands Ecological Site (State I, Fig. 2) is an oak (Quercus spp.) savanna with native tall grasses: little bluestem (Schizachyrium scoparium [Michx.] 
Nash), big bluestem (Andropogon gerardii Vitman), Indiangrass (Sorghastrum nutans [L.] Nash), switchgrass (Panicum virgatum L.), and Eastern gamagrass (Tripsacum dactyloides [L.] L.). Average herbaceous foliar cover is $>75 \%$ with $<25 \%$ bare ground.

Fire was an important factor in maintaining the original open prairie vegetation and plant community structure. Species such as Ashe juniper might have invaded the site but then receded with periodic fire. Woody plant cover varied in accordance with the type and frequency of disturbance and resulted in a mosaic of vegetation types within the same ecological site.

Historic overgrazing brought about the reduction of these native grasses from a large portion of the area. Heavy grazing reduced the fine fuels that help carry fire and facilitated rapid encroachment of Ashe juniper and associated woody species. In State III.4 (Fig. 2), the loss of topsoil and soil organic matter cannot be replenished in a human-management timeframe (decades); therefore, returning to the reference state (State I) is not possible once the site has crossed this ecological and hydrologic threshold.

On the Deep Redlands Ecological Site, Ashe juniper, because of its dense, low-growing foliage, has the ability to retard grass and forb growth. Grass and forb growth can become nonexistent and the diversity of native forbs and grasses dramatically reduced, whereas the presence of introduced and nonnative species can increase rapidly. Where soil loss has not been significant in overgrazed sites, little bluestem and other native species will slowly return to the site with sound management and proactive conservation.

Ashe juniper expansion has occurred during the past century and has accelerated in the past 50 years because of overgrazing and fire suppression. ${ }^{6}$ In 1985 , it was estimated that Ashe juniper occupied more than 8 million acres of Texas rangelands. ${ }^{6}$ The on-site data from rangeland NRI, collected from 2003 to 2006, showed that Ashe juniper had increased to 9.3 million acres. The greatest abundance of Ashe juniper is found on the eastern and southern portions of the Edwards Plateau, but Ashe juniper also extends into the South Texas Plains and north into the Cross Timbers and Rolling Plains areas of the state. ${ }^{7,8}$ Many of these ecological sites have juniper as a native component (with $5-10 \%$ cover). Historically, Ashe juniper is believed to have been restricted to rocky outcrops and rocky, north-facing slopes, where it was protected from intense grass fires. ${ }^{8}$ Ecological sites with Ashe juniper exceeding $10 \%$ are transitioning to an altered state with reduced ecosystem services.

When Ashe juniper canopy cover reaches about 30\% (depending on slope, soil profile characteristics, and other factors), biotic and hydrologic thresholds are often reached. Ashe juniper canopy closure rapidly increases from that point forward. As the Ashe juniper canopy increases and closes in, understory grasses and forbs become depauperate, and bare soil increases between mature junipers. On degraded and disturbed rangelands, an increase in runoff and soil loss with increasing land area is typical because of the increased connectedness of bare soil patches that allow the formation of concentrated flow paths, which, in turn, initiates accelerated soil loss, rills, and gullies. ${ }^{9,10}$ As Ashe juniper cover increases, the amount of precipitation that reaches the soil surface is significantly reduced. ${ }^{11-13}$ Canopy interception losses reach $36.7 \%$ of gross precipitation for Ashe juniper. ${ }^{11-13}$ As a comparison, a live oak canopy intercepts approximately $25.4 \%$ of gross rainfall. Rainfall that passes through the canopy is then intercepted by the dense litter layer under Ashe juniper, and the litter intercepts $40-43 \%$ of gross rainfall. Because of interception loss via the canopy and litter, only $32 \%$ of the annual rainfall reaches the mineral soil surface under the canopies of Ashe juniper. ${ }^{11-13}$ This can result in less water available for grasses, further reducing cover, and accelerating erosion potential. In comparison, $82 \%$ to $89 \%$ of annual precipitation reaches the soil surface with grass cover. ${ }^{12}$

With reference to the Ecological Site Description (Fig. 2), the oak savanna (Reference Plant Community) is associated with maximum hydrologic function (State I). The high degree of hydrologic function in State I is due to the dominance of rhizomatous, tall and mid grasses. When properly managed, these species provide adequate cover; however, one of the key factors affecting hydrologic function is the structure and morphology of the root system and other biotic and abiotic factors. During high rainfall periods, water will percolate beyond the immediate surface root zone via fractures in the predominantly limestone bedrock. As this water moves downward, it contributes to the recharge of aquifers and provides a constant source of subsurface water for sustained stream flow. When conditions are representative of tall and mid grass species (juniper canopy cover $<5 \%$ ), little runoff and soil loss occurs on an annual basis. As an example, for Johnson City, Texas, RHEM-estimated precipitation from the 2-year return period runoff event is 2.8 inches, surface runoff is 2.1 inches, and soil loss is 0.2 ton per acre for the reference condition (State I).

With the absence of fire and other conservation measures, Ashe juniper will invade the site. The most cost-effective treatment option is to treat the area before junipers reach a height of 4 feet and canopy cover exceeds $10 \%$. For sites with juniper cover of $<10 \%$, NRCS recommends that prescribed fire, mechanical brush removal, or hand-thinning and/or herbicides be used to keep the area in a State I savanna plant community (Fig. 3). This would cost approximately $\$ 24$ per acre once every 5-10 years. depending on rate of encroachment and specific site attributes. Grazing could be allowed following treatment depending on local weather conditions and site response.

Improper grazing management and lack of fire causes loss or reduction of the rhizomatous tall and mid grasses (State II). In State II, prolonged improper grazing management, no brush management or prescribed fire, and the introduction of invasive species results in impaired hydrologic function. During the transition phase from States I to II, infiltration de- 


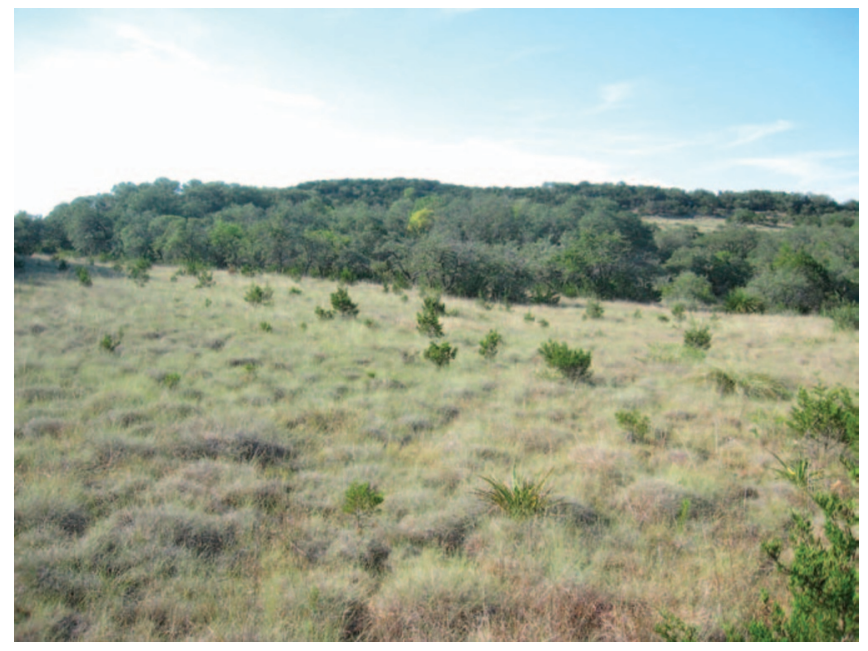

Figure 3. Deep Redlands Ecological Site in State I, illustrating early stages of invasion of junipers into the open grassland in the foreground. Spot treating with herbicide or hand thinning are cost-effective methods of treating this site.

creases, runoff increases, and soil loss may begin to accelerate because of shifts in grass composition from tall and mid species to short grass species, higher percentages of bare ground, soil compaction and capping, loss of organic matter, and deterioration in soil structure (Fig. 2). Hydrologic conditions worsen with continued improper management. When juniper canopy cover is between $10 \%$ and $30 \%$ (State II.3) and the trees are as tall as 12 feet, average treatment costs rise to $\$ 83$ per acre (and increase as juniper density and size increases) to return the site to State I. Technical assistance costs triple to $\$ 15$ per acre because of the complex design and implementation requirements for more intricate management plans. Mechanical brush management, hand thinning, and herbicide use will all be more extensive and expensive than in State I.2. If prescribed fire is not allowed or desired and herbicides are required, costs can be $\$ 135$ per acre. If there is substantial soil disturbance during mechanical treatments with heavy machinery, rangeland seeding may be needed which can increase the cost to more than $\$ 200$ acre. Grazing may have to be deferred for up to 2 years to allow for establishment of seeded species or natural regeneration, depending on initial condition of the site and local weather following treatment.

For the Johnson City, Texas, example, the RHEM-estimated two-year runoff event is 2.2 inches and the estimated soil loss is 1.2 tons per acre for State II.3 (juniper canopy cover near 20\%). The 50-year return period runoff soil loss value is triple the soil loss in the reference condition of State I (Table 1). With a combination of increasing bare ground and change in cover type and amount, this site can contribute to an increased frequency and severity of flooding within a watershed during intense rainfall events.

In State III.4, where Ashe juniper and associated woody species dominate the site (Fig. 2), understory species become increasingly sparse, and ground cover decreases because of

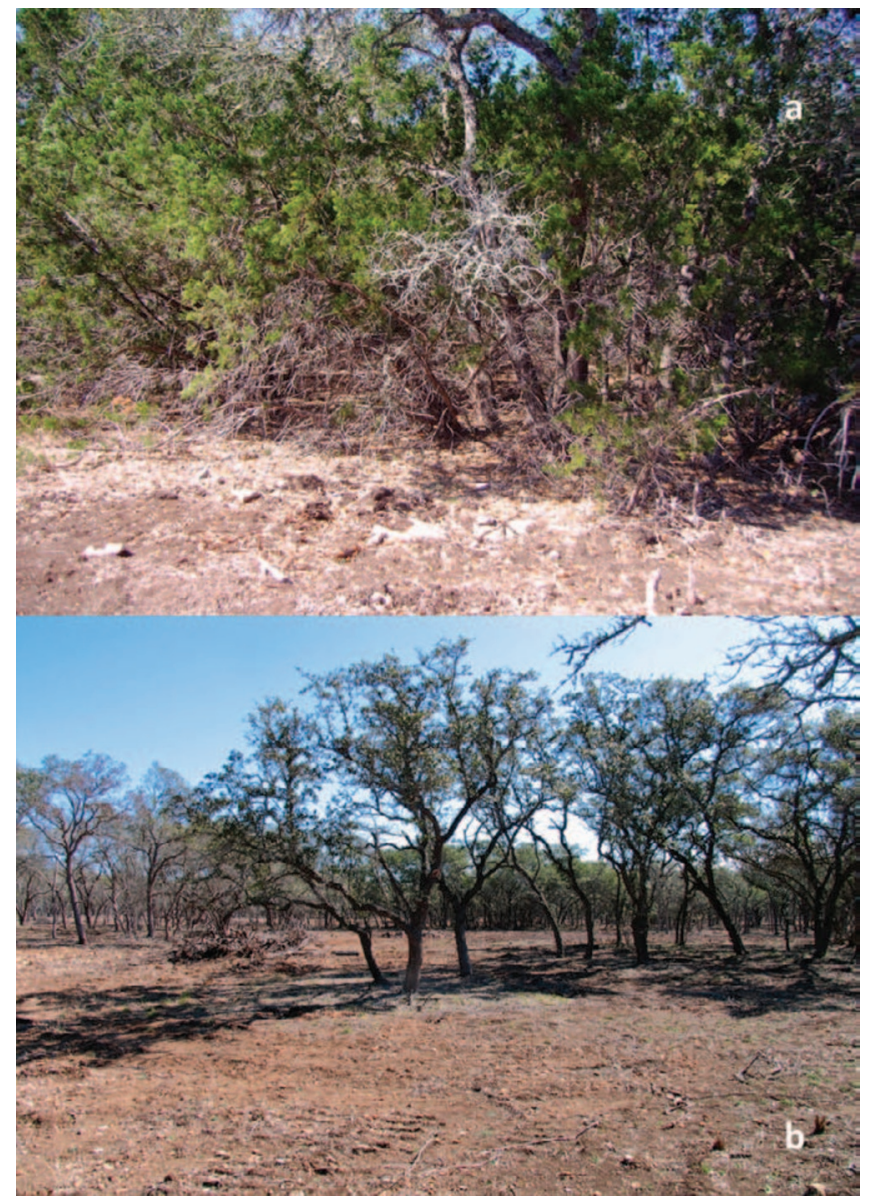

Figure 4. Deep Redlands Ecological Site in State III. a, Dense vegetation, no herbaceous understory, and large, bare spaces that are vulnerable to accelerated erosion. b, A site where mechanical brush control has been used to remove juniper. Notice the lack of understory under undisturbed oaks, brush piles, and soil disturbance from the use of heavy equipment to remove junipers (b). This site (b) is currently vulnerable to accelerated soil erosion because of extensive bare soil from the brush-control treatment and requires seeding of desired species and rest from grazing until herbaceous vegetation is reestablished to restore to State I.

shading and competition from woody plants. As Ashe juniper becomes mature ( $>20$ feet tall), juniper density and bare ground increases. When juniper canopy cover is $>30 \%$ and trees are taller than 20 feet (State III.4, Fig. 4), the expected minimum cost for treatment is $\$ 385$ per acre. Technical assistance rises to $\$ 20$ per acre, and mechanical brush management may require bulldozers to remove mature trees. Planting of adapted species because of severe soil-surface disturbance is usually required. Spot treatment with herbicide and physical removal or burning of brush piles are often required as part of the restoration effort and add significantly to the cost and complexity of restoration efforts. Deferred grazing for 2 years is recommended.

In State III.4, soil loss can accelerate rapidly because of loss of understory vegetation. The site can erode quickly, especially during rarer, high-intensity, climatic storm events (Table 1). Rills and gullies may form between mature juni- 
pers, which can concentrate the runoff and accelerate the soil erosion. RHEM-estimated erosion rates are increased by six times over the reference condition (juniper cover $<5 \%$ ) for the 50-year runoff return period event. Surface runoff is increased by 2.8 times when juniper canopy cover is $>30 \%$, compared with the reference condition for the 50-year runoff return period event.

If the site is allowed to deteriorate to a point where considerable soil loss has occurred, the site crosses an ecological threshold and can't be restored to its potential. If the site has not incurred significant soil loss, conservation treatments, including a combination of practices (brush management, prescribed grazing, prescribed burning, and rangeland seeding) can help restore the natural hydrology of the site to some degree. For example, in the early stages of State III.4, where the erosive phase has not been significant, it may be possible to revert to
State II. However, this window is "short lived," and often, once the plant community reaches State III.4, conditions deteriorate rapidly limiting options for restoring to State I.

\section{Conclusion}

On arid and semiarid rangelands, soil erosion is episodic in nature because of extremes in precipitation from year to year. Evaluation of long-term, average, annual soil loss on rangeland is inappropriate because, in many cases, water-induced soil erosion may not occur on arid or semiarid rangelands for many consecutive years to decades because of limited precipitation. However, this does not mean that rangelands are not susceptible and vulnerable to erosion. For example, in drought conditions, where vegetation production has been significantly reduced and bare ground has increased, once rainfall commences, the exposed bare soil surface is easily eroded

Table 1. Rangeland hydrology and erosion model estimates of runoff and soil loss during runoff events for Deep Redlands Ecological Sites in the Edwards Plateau, near Johnson City, Texas, USA

\section{Return period runoff frequency}

Precipitation (inches)
Runoff (inches)

Soil loss (tons per acre )

State I (reference state; juniper $<4$ feet and $<10 \%$ juniper canopy cover)

\begin{tabular}{|l|c|c|c|}
\hline 2 year & 2.8 & 2.1 & 0.2 \\
\hline 10 years & 4.3 & 2.5 & 0.7 \\
\hline 25 years & 5.4 & 3.6 & 0.9 \\
\hline 50 years & 5.6 & 4.6 & 1.1 \\
\hline
\end{tabular}

State II (juniper $>4$ feet and $<12$ feet and juniper canopy cover of $10-30 \%$ )

\begin{tabular}{|l|c|c|c|}
\hline 2 year & 2.8 & 2.2 & 1.2 \\
\hline 10 years & 4.3 & 4.3 & 2.8 \\
\hline 25 years & 5.4 & 5.6 & 3.2 \\
\hline 50 years & 5.6 & 7.9 & 3.5 \\
\hline
\end{tabular}

State III (juniper $>20$ feet and $>30 \%$ juniper canopy cover)

\begin{tabular}{|l|c|c|c|}
\hline 2 year & 2.8 & 2.3 & 2.1 \\
\hline 10 years & 4.3 & 6.8 & 3.0 \\
\hline 25 years & 5.4 & 8.3 & 5.3 \\
\hline 50 years & 5.6 & 13.1 & 6.7 \\
\hline
\end{tabular}


and concentrated flow paths may form. Rangelands are not manipulated annually like row crops. Once formed, concentrated flow paths (rills or ephemeral gullies on croplands) can accelerate soil erosion and the land degradation process. On rangelands, these concentrated flow paths facilitate water accumulation and accelerated soil loss in subsequent rainfall events resulting in the site crossing a hydrologic threshold and being permanently degraded..$^{14}$ Most of the soil loss on rangelands occurs during infrequent, intense storms that generate large amounts of runoff that scours the soil surface.

Modeling of soil erosion based on quantitative data from rangeland NRI can be used to predict the effectiveness of alternative management actions and support cost-benefit analyses to optimize return on investment in conservation. The spatially unbiased nature of the rangeland NRI assessment allows for rapid determination of regional needs and identification of where conservation may be most cost-effective in arresting land degradation and enhancing ecosystem services. This same concept can be used to inform policy and to provide a quantitative mechanism to justify targeting to meet specific goals as being cost effective. It is more costeffective to prevent soil loss than it is to restore a site after it has been significantly degraded - if it is even possible to restore a degraded site. Therefore, effective conservation planning should incorporate risk-based assessments by using return period runoff events, which would encourage proactive conservation implementation before those events occur.

\section{Acknowledgments}

We thank Laura Weltz, for creating the maps, and the many NRCS employees who collected and processed the NRI field data.

\section{References}

1. Duriancik, L. F., D. Bucks, J. P. Dobrowolski, T. Drewes, S. D. Eckles, L. Jolley, R. L. Kellogg, D. Lund, J. R. Makuch, M. P. O’Neill, C. A. Rewa, M. R. Walbridge, R. Parry, and Mark A. Weltz. 2008. The first five years of the Conservation Effects Assessment Project. Journal of Soil and Water Conservation 63:185A-197A.

2. Herrick, J. E., V. C. Lessard, K. E. Spaeth, P. L. Shaver, R. S. Dayton, D. A. Pyke, L. Jolley, and J. J. Goebel. 2010. National ecosystem assessments supported by scientific and local knowledge. Frontiers in Ecology and the Environment 8:403408. doi:10.1890/100017

3. Spaeth, K. E., G. L. Peacock, J. E. Herrick, P. Shaver, and R. Dayton. 2005. Rangeland field data techniques and data applications. Journal of Soil and Water Conservation 60:114A-119A.

4. Nearing, M. A., H. Wei, J. J. Stone, F. B. Pierson, K. E. Spaeth, M. A. Weltz, and D. C. Flanagan. 2011. A rangeland hydrology and erosion model. Transactions of the American Society of Agricultural and Biological Engineers 54:1-8.
5. Jolley, L., M. A. Weltz, J. Herrick, and the USDA GrazIng Land Team. 2011. Chapter 3. The State of the Land. In: Resource Conservation Act appraisal. Washington, DC, USA: USDA. p. 25-48.

6. Soil Conservation Service. 1985. Texas brush inventory. Temple, TX, USA: USDA.

7. Ellis, D., AND J. L. Schuster. 1968. Juniper age and distribution on an isolated butte in Garza County, Texas. Southwestern Naturalist 13:343-348.

8. Smeins, F. E., and S. D. Fuhlendorf. 1997. Biology and ecology of Ashe (blueberry) juniper. In: C. A. Taylor, Jr. [ED.]. Proceedings of the 1997 Juniper Symposium; 9-10 January 1997; San Angelo, TX, USA. San Angelo, TX, USA: Texas AgriLife Research and Extension Center. Chapter 3.4. Available at: http://texnat.tamu.edu/library/symposia/juniper-ecology-andmanagement/biology-and-ecology-of-ashe-juniper/.

9. Wilcox, B. P., D. D. Breshears, and C. D. Allen. 2003. Ecohydrology of a resource-conserving semiarid woodland: effects of scale and disturbance. Ecological Monographs 73:223-239.

10. Pierson, F. B., C. J. Williams, S. P. Hardegree, M. A. Weltz, J. J. Stone, and P. E. Clark. 2011. Fire, plant Invasions, and erosion events on western rangelands. Rangeland Ecology $\sigma^{\circ}$ Management 64:439-449.

11. Thurow, T. L., and D. H. Carlson. 1994. Juniper effects on rangeland watersheds. In: C. A. Taylor, Jr. [ED.]. Proceedings of the 1994 Juniper Symposium; 14 April 1994; Sonora, TX, USA. Sonora, TX, USA: Texas Agricultural Experiment Station. Technical Report 94-2. p. 31-43.

12. Hester, J. W. 1996. Influence of woody dominated rangelands on site hydrology and herbaceous production, Edwards Plateau, Texas [MS thesis]. College Station, TX, USA: Texas A\&M University.

13. Thurow, T. L., AND J. W. Hester. 1997. How an increase or reduction in juniper cover alters rangeland hydrology. In: C. A. Taylor, Jr. [ED.]. Proceedings of the 1997 Juniper Symposium; 9-10 January 1997; San Angelo, TX, USA. San Angelo, TX, USA: Texas AgriLife Research and Extension Center. Chapter 4.2. Available at: http://texnat.tamu.edu/library/symposia/juniper-ecology-andmanagement/biology-and-ecology-of-ashe-juniper/.

14. Urgeghe, A. M, D. D. Breshears, S. N. Martens, and P. C. BeEson. 2010. Redistribution of runoff among vegetation patch types: on ecohydrological optimality of herbaceous capture. Journal of Rangeland Ecology E Management 63:497-504.

Authors are Rangeland Hydrologist, USDA-ARS, $920 \mathrm{Val}$ ley Road, Reno, NV 89512, USA, mark.weltz@ars.usda.gov (Weltz); and Rangeland Hydrologist, USDA-NRCS Central National Technology Support Center, 501 W Felix Street, FWFC, Bldg 23, Fort Worth, TX 76115, USA (Spaeth). Support for this research was provided by the USDA Rangeland Research Program and the NRCS Conservation Effects Assessment Project (CEAP). USDA is an equal opportunity provider and employer. 